\title{
Value of multiple fecal indices for predicting diet quality and intake of steers
}

\author{
ENEAS R. LEITE AND JERRY W. STUTH
}

\section{Abstract}

The relationship of fecal nitrogen fractions and condensed tannins to dietary crude protein, in vitro organic matter digestibility, and intake of steers was assessed to determine the suitability of these multiple fecal indices for predicting quality of animal diets under free-roaming conditions. Research was conducted on the Texas A\&M Native Plant and Animal Conservancy near College Station, located in the Post Oak Savannah region of Texas. Regression equations were used to evaluate relationships between dietary intake and quality to fecal variables. Dietary crude protein, digestible organic matter, organic matter intake, crude protein intake, and digestible energy intake were determined from previous studies. Corresponding fecal samples were analyzed for absolute output, proportions, and concentrations of nitrogen and selected fractions of fecal organic matter, as well as fecal condensed tannins, proportions of fecal monocot and dicot fragments, and fecal organic matter. In general, no fecal parameter by itself had a high correlation with dietary variables when expressed on a proportion or concentration basis. A combination of fecal indexes accounted for more variation in dietary parameters than fecal nitrogen. Fecal nitrogen fractions did not improve the predictive power of multiple variable models. Equations predicting dietary crude protein (\%) and crude protein intake yielded the highest coefficients of determination $\left(R^{2}=.57\right.$ and .51 , respectively). Multiple fecal indices used in this study were of limited value in predicting diet quality and intake.

Key Words: fecal nitrogen fractions, diet prediction, diet quality, nutrient intake

Fecal nitrogen has repeatedly been shown to be the principal variable used for predicting diet quality of ruminants, particularly crude protein (Arnold and Sudzinski 1963, Jeffery 1971, Arman et al. 1975, Langlands 1975, Holechek et al. 1981, Mubanga et al. 1985, Wofford et al. 1985, and Shaabani et al. 1986). However, repeatability and accuracy has been hampered due to the wide array of plant species consumed by ruminants across landscapes and between seasons (Lamborne and Reardon 1963, Holechek et al. 1982, Mubanga et al. 1985). Holloway et al. (1981) attempted to overcome this deficiency by analyzing fecal dry matter, fecal cell wall constituents, and fecal ether extract in addition to fecal nitrogen. Approximately $70 \%$ of the observed variation in diet digestibility could be accounted for in their data set.

Fecal nitrogen indices have shown limited value in predicting diet quality when soluble phenolics or tannins are high in diets (Mould and Robbins 1981, Natis and Malechek 1981, Shidahmed et al. 1981). Given the problems of varied diets, fractionation of nitrogen constituents, and reported improved predictions of diet quality with multiple variable fecal indices, we felt that prediction of diet quality and intake via wet chemistry could be enhanced

\footnotetext{
Authors are currently research scientist, Agricultural Research Co. of Paraiba Authors are currently research scientist, Agricultural Research Co. of Paraiba
State, Ar. Epitacio Pessoa, 1883, 58000 Joao Pessoa, Paraiba, Brazil; and professor, Department of Range Science, Texas A\&M University, College Station 77843.

This manuscript was published with the approval of the Director, Texas Agricultural Experiment Station, Texas A\&M University System as TA-23671.

The authors would like to acknowledge Drs. Larry Vamer and Bill Holloway, Texas Agricultural Research and Extension Center-Uvalde, Texas, for use of their tannin laboratory and critical review of this manuscript.

Manuscript accepted 16 March 1989.
}

through analysis of various fecal nitrogen fractions and other fecal components, particularly condensed tannins. Our hypothesis was that plant nitrogen in feces could be more accurately reflected by determining nitrogen content of various insoluble fractions. Nitrogen fractionation coupled with fecal condensed tannins should provide the necessary information to more accurately predict diet quality given the reported successes of prior studies on more simple diets.

\section{Methods}

The study area was located on the Texas A\&M Native Plant and Animal Conservancy, approximately $7 \mathrm{~km}$ southwest of College Station (30.37N, 96.21W). The area is representative of the Post Oak (Quercus stellata) Savannah region of Texas (Gould 1975) and is dominated by little bluestem (Schizachyrium scoparium) and brownseed paspalum (Paspalum plicatulum).

Fecal and associated dietary samples were obtained from a study conducted by Olson (1984) and reported by Stuth et al. (1987). Dietary and fecal samples selected represented the variation found in diets of steers ( $3 / 4$ Hereford and $1 / 4$ Brahman) averaging $265 \mathrm{~kg}$ and stocked at 4 rates in 12 grazing cycles across 2 years in a simulated 16-pasture, 1-herd, short-duration grazing system. Both fecal and extrusa samples were composited across animals by day to generate the appropriate independent and dependent variables. Equal 5-g subsamples were obtained from ground samples of each animal's extrusa to construct the composited sample. These composited fecal samples were paired with average diet samples collected $24 \mathrm{hr}$ prior to fecal collection. Intake variables were calculated with 24-hr pre-fecal output estimates of indigestible organic matter (100-DOM). A total of 293 samples were incorporated into this study to represent the variation in grazed situations.

All fecal samples were dried at $60^{\circ} \mathrm{C}$ in a forced air convection oven for $\mathbf{4 8} \mathrm{hr}$ and then ground in a Wiley mill to pass a 2-mm screen. Chemical analyses performed were dry matter, organic matter, total nitrogen (AOAC 1976), insoluble nitrogen (Goering and Van Soest 1970), and fecal condensed tannins based on the colormetric catechin method (Jones et al. 1976). Fecal monocotyledon and dicotyledon proportions were also assessed using a $120 \mathrm{x}$ dissecting microscope and counting fragments in 20 fields for each of 5 microscope slides per sample. Total nitrogen and its fractions was determined by multiplying fecal output ( $\mathrm{kg} /$ day) times proportion of fraction in feces ( $\mathrm{g} / \mathrm{g}$ FOM).

Residuals were plotted against predicted values, and independent variables were tested for violations of assumptions and were used to assess curvilinearity. Tests of correlation were made among fecal parameters. Some independent variables were deleted from the models when multicollinearity was detected (Montgomery and Peck 1982, SAS 1982). Regression equations were determined using the stepwise method (SAS 1982) to evaluate predictive relationships between the dependent variables dietary crude protein, digestible organic matter, organic matter intake, crude protein intake, and digestible energy intake, to the independent variables total fecal nitrogen, concentration of nitrogen in fractions ( $g$ of $\mathrm{N} / \mathrm{g}$ fraction $\mathrm{OM}$ ), proportion of nitrogen fractions ( $\mathrm{g}$ of $\mathrm{N} / \mathrm{g}$ of 
Table 1. Coefficients of simple correlation ( $r$ ) between fecal organic matter (OM), proportion of fecal monocot fragments (PROFM), fecal tannins (FTAN), concentrations (\%) of fecal nitrogen (FN), insoluble nitrogen (INSN) soluble nitrogen (SOLN), and SOLN/INSN ratio (SIR), and proportions (gN/G fecal OM) of total nitrogen (GFN), insoluble nitrogen (GIN), soluble nitrogen (GSN), and GSN/GIN ratio (PSIR).

\begin{tabular}{|c|c|c|c|c|c|c|c|c|c|c|}
\hline Independent variables & $\mathrm{OM}$ & PROFM & FN & INSN & SOLN & GFN & GIN & GSN & SIR & PSIR \\
\hline FTAN & -0.01 & -0.15 & -0.30 & -0.43 & -0.01 & -0.30 & -0.33 & -0.22 & 0.23 & 0.12 \\
\hline OM & & -0.08 & -0.45 & -0.32 & -0.37 & -0.45 & 0.07 & -0.53 & -0.04 & 0.53 \\
\hline PROFM & & & 0.03 & 0.31 & -0.18 & 0.03 & 0.14 & -0.01 & -0.37 & -0.09 \\
\hline FN & & & & 0.67 & 0.08 & 1.00 & 0.55 & 0.97 & 0.22 & 0.34 \\
\hline INSN & & & & & 0.17 & 0.67 & 0.83 & 0.50 & -0.56 & -0.27 \\
\hline SOLN & & & & & & 0.84 & 0.13 & 0.92 & 0.69 & 0.65 \\
\hline GFN & & & & & & & 0.55 & 0.97 & 0.22 & 0.34 \\
\hline GIN & & & & & & & & 0.32 & -0.46 & -0.57 \\
\hline GSN & & & & & & & & & 0.38 & 0.57 \\
\hline SIR & & & & & & & & & & 0.70 \\
\hline
\end{tabular}

fecal OM), proportions of fecal monocot fragments, fecal tannins, and fecal organic matter.

\section{Results and Discussion}

\section{Relationship between Fecal Parameters}

Total fecal nitrogen ( $\mathrm{gN} / \mathrm{g}$ fecal $\mathrm{OM}$ ) was most highly related to the soluble nitrogen fraction in feces $(r=0.97)$, while a weaker relationship existed between total fecal nitrogen and the insoluble fraction $(r=0.55)$ (Table 1). As forage quality declines, the ratio of insoluble nitrogen in feces increases in relation to soluble nitrogen (Naik 1967, Ford 1978, Ford et al. 1979), as was demonstrated in this study. Proportion of fecal monocot fragments decreased with an increasing ratio of fecal soluble/insoluble nitrogen concentration.

Soluble fecal nitrogen is mostly of microbial and endogenous origin, while insoluble nitrogen is primarily of plant origin (Orskov 1982, Van Soest 1982). In this study, fecal organic matter was negatively correlated with proportion and concentration of soluble fecal nitrogen (Table 1). As fecal organic matter increased, the solubility of nitrogen decreased, and consequently, fecal ash and fecal soluble nitrogen are positively related. Apparently, soluble fecal nitrogen is primarily of microbial origin, while insoluble fecal nitrogen is of plant origin.

Fecal condensed tannins (catechins) were negatively correlated with all fecal variables, but most highly correlated with insoluble nitrogen (Table 1). This was an unexpected observation. Several studies (Feeney and Bostock 1968, Tamir and Alumot 1969, Milic et al. 1972, Griffiths 1979, Barry and Duncan 1984), have indicated tannins have the capacity to bind with proteins to form complexes that are indigestible. However, in this study the proportion of insoluble nitrogen in the feces increased as diet quality increased. Such a relationship could occur if the binding capacity of the tannins extracted were weak. The method used possibly did not extract plant condensed tannins, but only tannins not precipitated or strongly bound to proteins.

Proportions of fecal condensed tannins cxhibited a negative correlation with percent of fecal monocot fragments. This negative correlation would be expected to be higher than observed, since tannins are much more common in dicots than in monocot species (White 1957, McLeod 1974, Price and Butler 1984). However, in this study the fecal monocot/dicot fragments ratio was high all grazing cycles, thereby masking any possible relationship between fecal tannins and fecal monocot fragments. This could be a function of a low browse availability in the study area and in associated diets (Stuth et al. 1987). On the other hand, the fecal monocot fragments were larger than the dicot fragments. If proportions of monocots and dicots were measured based on amount of monocot and dicot in fecal samples, instead of proportions of fragments, a stronger negative relationship may have occurred between fecal condensed tannins and fecal monocots. Again, the reasons may reside in the extraction method used.

\section{Prediction of Diet Quality}

Concentration of insoluble nitrogen in fecal organic matter was the most important single variable in estimating dietary crude protein $(r=0.60)$, but proportion of soluble nitrogen in fecal organic matter had a similar relationship $(r=0.57)$ (Table 2). Consequently, the best equation for prediction of dietary crude protein contains these 2 variables. Fecal condensed tannins, proportions of fecal monocot fragments, and fecal organic matter,

Table 2. Cuefficients of simple correlation between dietary and fecal parameters.

\begin{tabular}{|c|c|c|c|c|c|}
\hline \multirow[b]{2}{*}{ Fecal variables } & \multicolumn{5}{|c|}{ Dietary parameters } \\
\hline & Crude protein & $\begin{array}{c}\text { Digestible organic } \\
\text { matter }\end{array}$ & $\begin{array}{c}\text { Organic matter } \\
\text { intake }\end{array}$ & $\begin{array}{c}\text { Crude protein } \\
\text { intake }\end{array}$ & $\begin{array}{c}\text { Digestible energy } \\
\text { intake }\end{array}$ \\
\hline $\begin{array}{l}\text { Fecal tannins } \\
\text { Proportion of fecal monocots } \\
\text { Fecal organic matter }\end{array}$ & $\begin{array}{r}-0.38 \\
0.35 \\
-0.47\end{array}$ & $\begin{array}{r}-0.42 \\
0.31 \\
-0.20\end{array}$ & $\begin{array}{r}-0.14 \\
0.54 \\
0.11\end{array}$ & $\begin{array}{r}-0.25 \\
0.53 \\
-0.12\end{array}$ & $\begin{array}{r}-0.22 \\
0.51 \\
0.01\end{array}$ \\
\hline \multicolumn{6}{|c|}{$\mathrm{N}$ concentration (\% $\mathrm{N}$ in fecal $\mathrm{OM}$ ) } \\
\hline $\begin{array}{l}\text { Total nitrogen } \\
\text { Insoluble nitrogen (INSN) } \\
\text { Soluble nitrogen (SOLN) } \\
\text { SOLN/INSN N ratio }\end{array}$ & $\begin{array}{r}0.59 \\
0.60 \\
0.36 \\
-0.17\end{array}$ & $\begin{array}{r}0.48 \\
0.48 \\
0.30 \\
-0.13\end{array}$ & $\begin{array}{r}0.21 \\
0.38 \\
0.01 \\
-0.27\end{array}$ & $\begin{array}{r}0.47 \\
0.56 \\
0.22 \\
-0.25\end{array}$ & $\begin{array}{r}0.36 \\
0.46 \\
0.16 \\
-0.23\end{array}$ \\
\hline \multicolumn{6}{|l|}{ N proportion (gN/g fecal OM) } \\
\hline $\begin{array}{l}\text { Total nitrogen } \\
\text { Insoluble nitrogen (INSN) } \\
\text { Soluble nitrogen (SOLN) } \\
\text { SOLN/INSN N ratio } \\
\end{array}$ & $\begin{array}{l}0.59 \\
0.31 \\
0.57 \\
0.24\end{array}$ & $\begin{array}{l}0.48 \\
0.38 \\
0.43 \\
0.03\end{array}$ & $\begin{array}{r}0.21 \\
0.36 \\
0.13 \\
-0.18\end{array}$ & $\begin{array}{r}0.47 \\
0.45 \\
0.39 \\
-0.04\end{array}$ & $\begin{array}{r}0.36 \\
0.42 \\
0.28 \\
-0.11\end{array}$ \\
\hline
\end{tabular}


Table 3. Regression equations for predicting diet quality.

\begin{tabular}{|c|c|c|c|c|}
\hline Source & Regression equation! & $R^{2}$ & Sxøy & CV \\
\hline & \multicolumn{4}{|l|}{ Dietary crude protein $(n=287)$} \\
\hline Fecal N & $12.451+12.07(\mathrm{FN})+0.04(\mathrm{PROFM})-0.25(\mathrm{FTAN})-12.73(\mathrm{OM})$ & $\begin{array}{l}0.52 \\
P=.0001\end{array}$ & 1.11 & 15.2 \\
\hline $\mathbf{N}$ fractions conc. & $9.01+4.27($ INSN)+1.58(SOLN)+0.04(PROFM)-10.95(OM) & $\begin{array}{l}0.51 \\
P=.0001\end{array}$ & 1.12 & 15.3 \\
\hline $\mathbf{N}$ fractions prop. & $11.60+234.26(\mathrm{GSN})+0.04(\mathrm{PROFM})-0.28(\mathrm{FTAN})-11.22(\mathrm{OM})$ & $\begin{array}{l}0.51 \\
P=.0001\end{array}$ & 1.13 & 15.3 \\
\hline Mixed prop./conc. & $\begin{array}{l}10.14+171.02(\mathrm{GSN})+2.56(\text { INSN })-0.20(\mathrm{FTAN})+004(\mathrm{PROFM}) \\
-10.26(\mathrm{OM})\end{array}$ & $\begin{array}{l}0.55 \\
P=.0001\end{array}$ & 1.09 & 15.1 \\
\hline \multirow[t]{2}{*}{ Soluble $\mathbf{N}$ /insoluble $\mathbf{N}$ ratio } & $-0.92+0.73(\mathrm{PSIR})+6.11(\mathrm{INSN})-0.17(\mathrm{FTAN})+0.03$ (PROFM) & $\begin{array}{l}0.57 \\
P=.0001\end{array}$ & 1.08 & 14.9 \\
\hline & \multicolumn{4}{|l|}{ Digestible organic matter $(n=287)$} \\
\hline Fecal $\mathbf{N}$ & $30.23+9.70(\mathrm{FN})+0.18(\mathrm{PROFM})-1.46(\mathrm{FTAN})$ & $\begin{array}{l}0.37 \\
P=.0001\end{array}$ & 5.84 & 11.1 \\
\hline $\mathbf{N}$ fractions conc. & $30.31+11.83($ INSN) $+8.63(\mathrm{SOLN})+0.16(\mathrm{PROFM})-1.39(\mathrm{FTAN})$ & $\begin{array}{l}0.37 \\
P=.0001\end{array}$ & 5.84 & 11.1 \\
\hline $\mathrm{N}$ fractions prop. & $\begin{array}{l}29.24+1455.14(\mathrm{GIN})+899.66(\mathrm{GSN})+0.18(\mathrm{PROFM})-1.38 \\
(\mathrm{FTAN})\end{array}$ & $\begin{array}{l}0.37 \\
P=.0001\end{array}$ & 5.86 & 11.2 \\
\hline Mixed prop./conc. & $32.23+794.93(\mathrm{GSN})+7.52(\mathrm{INSN})-1.42(\mathrm{FTAN})+0.16(\mathrm{PROFM})$ & $\begin{array}{l}0.37 \\
P=.0001\end{array}$ & 5.89 & 11.2 \\
\hline Soluble $\mathbf{N}$ / insoluble $\mathbf{N}$ ratio & $34.02+1.30($ PSIR $)+16.55($ INSN)$)-1.46($ FTAN) +0.12 (PNFM) & $\begin{array}{l}0.34 \\
P=.0001\end{array}$ & 5.91 & 11.3 \\
\hline
\end{tabular}

${ }^{1} \mathrm{FIN}$ = fecal nitrogen; INSN = content of insoluble nitrogen; SOLN = cnc. of soluble nitrogen; GIN = proportion of insoluble nitrogen; GSN = proportion of soluble nitrogen; FTAN = fecal tannins; PROFM = proportion of fecal monocot fragments; OM = fecal organic matter; PSIR = proportion of soluble $\mathrm{N} /$ insoluble $\mathbf{N}$ ratio.

together in the model, improved the equation (Table 3).

Arman et al. (1975), Robbins (1983), Leslie and Starkey (1985, 1987) and Shaabani et al. (1986) have found that increases in dietary crude protein are directly related to increases in fecal nitrogen. ADF-N of the diet is generally a very small fraction of fecal N (Mason and White 1971). According to Orskov (1982), only a small fraction of fecal nitrogen is associated with dietary protein. He argues that fecal nitrogen consists of several fractions of different origin such as rumen microbial protein $\mathrm{N}$ as well as indigestible dietary nitrogen. Kothmann and Hinnant (1987), however, found ADF insoluble nitrogen in diets similar to ADF insoluble nitrogen in feces of goats, indicating the procedure probably recovered most of the protein in the feces that was bound in the diet.

Total fecal nitrogen and concentration of insoluble nitrogen in fecal $O M$ were the single variables best related to dietary digestible organic matter $\left(R^{2}=0.23\right.$ and $r=0.23$, respectively) (Table 2). The addition of fecal monocot fragments and fecal tannins to the predictive model increased $R^{2}$ values to 0.37 . Proportion of fecal monocot fragments were positively related with digestible organic matter (DOM) (Table 2). Shaabani et al. (1986) found fecal soluble nitrogen was the best single variable in predicting organic matter digestibility $\left(R^{2}=0.29\right)$. However, when they included fecal monocot fragments in the equation, $R^{2}$ values increased to 0.34 . Use of fecal tannins did not improve their predictive equations. Wofford et al. (1985) also found a low relationship between digestibility of organic matter and fecal nitrogen $\left(R^{2}=0.10\right.$ and 0.11 , respectively). In the present study, fecal tannins were negatively correlated with dietary DOM (Table 2). Similarly, McLeod (1974) and Kumar and Singh (1984) also reported tannins reduce digestibility of consumed forage.

\section{Prediction of Dietary Intake}

The most important single proportion of concentration variable for estimating organic matter intake was proportion of fecal monocot fragments (Table 2). Both concentration and proportion of fecal insoluble nitrogen contributed to the multiple regression equations. Shaabani et al. (1986) found insoluble nitrogen was the most important variable in estimating organic matter intake. Barry and Duncan (1984) reported organic matter intake is affected by tannin levels, but in this study the coefficient of correlation between the dependent variable and fecal tannins was low (Table 2). The best equation for prediction of organic matter intake was based on concentration of nitrogen fractions in fecal OM, but almost no improvement was obtained if compared with equations based on total fecal nitrogen and proportion of nitrogen fractions in fecal organic matter (Table 4).

Concentration of fecal insoluble nitrogen in the fecal NDF organic matter fraction was the most important single variable in estimating crude protein intake $(r=0.56)$. Proportion of fecal monocot fragments also had a relatively high correlation $(r=0.53)$ with crude protein intake (Table 2). The best prediction model included concentration of nitrogen fractions in fecal organic matter. Little improvement in $\boldsymbol{R}^{2}$ was noted in relation to those equations based on total fecal nitrogen or insoluble nitrogen proportions in fecal organic matter (Table 4).

The most important single variable for estimating digestible energy intake was proportion of fecal monocot fragments, which concurs with Holechek et al. (1982), who demonstrated that digestible energy of diets increased with increasing percent of grass in diets. Proportion of soluble nitrogen and concentration of insoluble nitrogen in organic matter were also positively correlated with digestible energy intake. No differences were found between the best equations based on total fecal nitrogen, concentration of fecal nitrogen fractions in organic matter, proportions of nitrogen fractions in organic matter, and mixed proportion and concentration of nitrogen fractions. All equations had low $R^{2}$ values (Table 4), indicating that the fecal parameters studied are poor variables for prediction of digestible energy intake in this particular study. Holmes (1980) stated that because of their varying chemical composition, the energy value of the herbage also varies. Grasses are generally more rich in digestible energy than browse, and as forage matures, digestible energy tends to decrease (Holmes 1980). Con- 
Table 4. Regresdion equations for predicting nutrient intake $(n=287)$.

\begin{tabular}{|c|c|c|c|c|}
\hline Source & Regression equation ${ }^{1}$ & $R^{2}$ & Sx॰y & $\mathrm{CV}$ \\
\hline & Organic matter intake & & & \\
\hline Fecal N & $-20.44+1.99(\mathrm{FN})+0.10(\mathrm{PROFM})+16.47(\mathrm{OM})$ & $\begin{array}{l}0.40 \\
P=.0001\end{array}$ & 1.39 & 30.8 \\
\hline $\mathrm{N}$ fractions conc. & $-19.93+3.42(\mathrm{INSN})+1.20(\mathrm{SOLN})+0.03(\mathrm{PROFM})+16.49(\mathrm{OM})$ & $\begin{array}{l}0.42 \\
P=.0001\end{array}$ & 1.37 & 30.5 \\
\hline $\mathrm{N}$ fractions prop. & $\begin{array}{l}-17.58+481.22(\mathrm{GIN})+130.27(\mathrm{GSN})+0.09(\mathrm{PROFM}) \\
+13.22(\mathrm{OM})\end{array}$ & $\begin{array}{l}0.41 \\
P=.0001\end{array}$ & 1.36 & 30.1 \\
\hline \multirow[t]{2}{*}{ Soluble $\mathbf{N}$ /insoluble $\mathbf{N}$ ratio } & $-3.41-0.17(\mathrm{PSIR})+2.46(\mathrm{INSN})-0.8(\mathrm{PROFM})$ & $\begin{array}{l}0.35 \\
P=.0001\end{array}$ & 1.43 & 33.2 \\
\hline & Crude protein intake & & & \\
\hline Fecal $\mathbf{N}$ & $1.54+0.30(F N)+0.01($ PROFM $)+0.84(O M)$ & $\begin{array}{l}0.48 \\
P=.0001\end{array}$ & 0.12 & 36.0 \\
\hline $\mathrm{N}$ fractions conc. & $1.48+0.47($ INSN $)+0.20($ SOLN $)+0.01($ PROFM $)+0.83(\mathrm{OM})$ & $\begin{array}{l}0.51 \\
P=.0001\end{array}$ & 0.12 & 35.1 \\
\hline $\mathbf{N}$ fractions prop. & $-1.25+57.64(\mathrm{GIN})+23.31(\mathrm{GSN})+0.01(\mathrm{PROFM})+0.50(\mathrm{OM})$ & $\begin{array}{l}0.49 \\
P=.0001\end{array}$ & 0.13 & 34.0 \\
\hline Mixed prop./conc. & $-1.64+20.85(\mathrm{GSN})+0.37(\mathrm{INSN})+0.01(\mathrm{PROFM})+1.04(\mathrm{OM})$ & $\begin{array}{l}0.51 \\
P=.0001\end{array}$ & 0.11 & 34.2 \\
\hline \multirow[t]{2}{*}{ Soluble $\mathbf{N}$ / insoluble $\mathbf{N}$ ratio } & $-0.64+0.02($ PSIR $)+0.52($ INSN $)+0.01($ PROFM $)$ & $\begin{array}{l}0.47 \\
P=.0001\end{array}$ & 0.12 & 35.1 \\
\hline & Digestible energy intake & & & \\
\hline Fecal N & 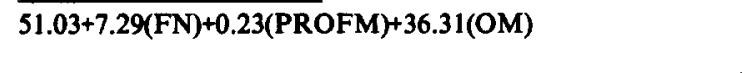 & $\begin{array}{l}0.41 \\
P=.0001\end{array}$ & 3.62 & 36.7 \\
\hline $\mathbf{N}$ fractions conc. & $-49.50+10.88(\mathrm{INSN})+5.13(\mathrm{SOLN})+0.21(\mathrm{PROFM})+36.03(\mathrm{OM})$ & $\begin{array}{l}0.42 \\
P=.0001\end{array}$ & 3.58 & 36.3 \\
\hline $\mathbf{N}$ fractions prop. & $\begin{array}{l}-42.55+1512.23(\mathrm{GIN})+529.62(\mathrm{GSN})+0.22(\mathrm{PROFM})+ \\
26.69(\mathrm{OM})\end{array}$ & $\begin{array}{l}0.42 \\
P=.0001\end{array}$ & 3.59 & 36.2 \\
\hline Mixed prop./conc. & $-52.69+506.68(\mathrm{GSN})+8.38(\mathrm{INSN})+0.20(\mathrm{PROFM})+40.77(\mathrm{OM})$ & $\begin{array}{l}0.42 \\
P=.0001\end{array}$ & 3.53 & 36.4 \\
\hline Soluble $\mathbf{N}$ / insoluble $\mathbf{N}$ ratio & $-11.85-0.01($ PSIR)+9.81(INSN)-0.10(FTAN)+0.18(PROFM) & $\begin{array}{l}0.40 \\
P=.0001\end{array}$ & 3.63 & 36.9 \\
\hline
\end{tabular}

IFIN =fecal nitrogen; INSN = content of insoluble nitrogen; SOLN = cnc. of soluble nitrogen; GIN = proportion of insoluble nitrogen; GSN = proportion of soluble nitrogen; FTAN = fecal tannins; PROFM = proportion of fecal monocot fragments; $O M=$ fecal organic matter; PSIR = proportion of soluble $N /$ insoluble $N$ ratio.

sequently, this is a condition-specific response and not reflective of some biological or physiological processes.

When total and fractional fecal nitrogen output per day was regressed against daily organic matter intake (OMI), total fecal nitrogen output per day was most highly correlated with OMI (Table 5). Kothmann and Hinnant (1987) found a similar relation-

Table 5. Relationship of total (GFN), NDF soluble (GSN) and NDF insoluble (GIN) fecal output ( $/ 8$ FOM/day) and organic matter intake (OMI) (\%BW/day) of steers $(\mathrm{N}=287)$.

\begin{tabular}{lccc}
\hline \hline Equation & $R^{2}$ & Sx॰y & CV \\
\hline OMI $=.274+.1259$ (GFN) & 0.84 & 0.94 & 15.4 \\
OMI $=.330+.1607$ (GSN) & 0.80 & 0.78 & 17.1 \\
OMI $=1.130+.4450$ (GIN) & 0.75 & 0.71 & 19.5 \\
\hline
\end{tabular}

ship with goats. The soluble NDF nitrogen fraction of fecal output accounted for more variation in OMI than insoluble NDF fecal nitrogen output.

\section{Conclusions}

No single fecal variable exhibited a strong relationship to the dependent variables studied. In general, the independent variable insoluble nitrogen yielded the highest single correlation with the dietary parameters. However, no improvement was found in equations based on nitrogen fractions when compared with those based on total fecal nitrogen. This can be explained by a lower correlation between fecal nitrogen and the other fecal variables studied, than correlations between the same variables and insoluble nitrogen fractions. As a consequence, the multiple regressions based on total fecal nitrogen had a higher relative increase in $R^{2}$ than those based on nitrogen fractions.

One promising aspect of the study indicated a strong relationship between total fecal nitrogen output and organic matter intake (Table 5). An underlying assumption in application of these equations would be the biological reliability of constant daily fecal output of a given class of animal. Ellis et al. (1982) has shown that fecal output remains relatively constant over a range of digestibilities as long as forage supply is not limiting, but varies with physiological status and kind and class of animal. Therefore, more knowledge relative to fecal output is required to pursue this avenue of research.

Unfortunately, we must reject our original hypothesis and catalog this study with the prior studies which marginally predicted dietary quality and nutrient intake. Many of the reservations expressed by Mason and White (1971), Orskov (1982), Hobbs (1987) and other authors, appear to continue to warn researchers of the difficulties in seeking wet chemistry techniques for predicting dietary quality and nutrient intake from fecal parameters.

\section{Literature Cited}

AOAC 1975. Official methods of analysis (12th Ed.). Assoc. Offic. Agr, Chem. Washington D.C. 
Arman, P., D. Hopcraft, and I. McDonald. 1975. Nutritional studies on East African herbivores. 2. Losses of nitrogen in the feces. Br. J. Nutr. 33:265-275.

Arnold, G.W., and M.L. Dudzinski. 1963. The use of fecal nitrogen as an index for estimating the consumption of herbage by grazing animals. J. Agr. Sci. 61:33-43.

Barry, T.N., and J.J. Duncan. 1984. The role of condensed tannins in the nutritional value of Lotus pendunculatus for sheep. 1. Voluntary intake. Br. J. Nutr. 54:485-491.

Bredon, R.M., K.N. Harker, and B. Marshall. 1963. The nutritive value of grasses in Uganda when fed to Zebu cattle. 2. The relation between percentage of crude protein and other nutrients. J. Agr. Sci. 61:101-104.

Brown, B.R., and C.H. Love. 1961. Protein-fixing constituents of plants, p. 90-93. In: Report of Forest Research, Her Majesty's Stationary Office, London.

Ellis, W.C., Lascano, R. Tecter, and F.N. Owens. 1982. Solute and particulate flow markers, p. 37-56. In: Protein Requirements for Cattle, Oklahoma State Univ. Pub. MP-109.

Feeney, P.P., and H. Bostock. 1968. Seasonal changes in the tannin content of oak leaves. Phytochem. 7:871-880.

Fels, H.G., R.J. Meir, and R.C. Rossiter. 1959. Herbage intake of grazing sheep in Southwestern Australia. Austr. J. Agr. Res. 10:236-247.

Ford, C.W. 1978. Effects of partial delignification on the in vitro digestibility of cell wall polysaccarides in Digitaria decumbens (pangola grass). Austr. J. Agr. Res. 29:1157-1166.

Ford, C.W., I.M. Morrison, and J.R. Wilson. 1979. Temperature effect on lignin and hemicellulose in tropical and temperature grasses. Austr. J. Agr. Res. 30:621-633.

Goering, H.K., and P.J. Van Soest. 1970. Forage fiber analysis (Apparatus, reagents, procedures and some applications). ARS, USDA Agr. Handbk. 379.

Gould, F.W. 1975. Texas plants: A checklist and ecological summary. Texas Agr. Exp. Sta. MP-585.

Griffiths, D.W. 1979. the inhibition of digestive enzymes by extracts of field bean (Vicia faba). J. Sci. Food Agr. 30:458-462.

Hobbs, N.T. 1987. Fecal indices to dietary quality: A critique. J. Wildl. Manage. 51:317-320.

Holechek, J.L., M. Vavra, and D. Arthun. 1982. Relationships between performance, intake, diet nutritive quality, and fecal nutritive quality of cattle on mountain ranges. J. Range Manage. 35:741-744.

Holechek, J.L., M. Vavra, and R.D. Pieper. 1982. Methods for determining the nutritive quality of range ruminant diets: A review. J. Anim. Sci. $54: 363-376$

Holloway, J.W., R.E. Estell, and W.T. Butts, Jr. 1981. Relationships between fecal components and forage consumption and digestibility. J. Anim. Sci. 52:836-848.

Holmes, W. 1980. Grass-Its production and utilization. Blackwell Scientific Publications, London.

Jeffery, H. 1971. Assessment of fecal nitrogen as an index for estimating digestibility and intake of food by sheep on Pennisetum clandestinum based pastures. J. Agr. Anim. Hus. 11:393-396.

Jones, W.T., R.B. Broadhurst, and J.W. Lyttleton. 1976. The condensed tannins of pasture legume species. Phytochem. 15:1407-1409.

Kothmann, M.M., and R.T. Hinnant. 1987. Direct measure of nutritional status of grazing animals, pp. 17-22. In: Proc. Symp. Monitoring Animal Performance and Production, Soc. Range Manage., Denver, Colo.

Kumar, R., and M. Singh. 1984. Tannins: Their adverse role in ruminant nutrition. J. Agr. Food Chem. 32:447-452.

Lambourne, L.J., and T.F. Reardon. 1963. The use of chromium oxide and fecal nitrogen concentration to estimate the pasture intake of merino wethers. Austr. J. Agr. Res. 14:257-271.

Lancaster, R.J. 1949. The measurements of feed intake by grazing cattle and sheep. I. A method of calculating the digestibility of pasture based on the nitrogen content of the feces derived from the pasture. N.Z.J. Sci. Tech. Sect. 31:31-38. anglands, J.P. 1975. Techniques for estimating nutrient intake and its utilization by the grazing ruminant. In: I.W. McDonald and A.C.I. Warner (ed.). Digestion and Metabolism in the Ruminant. The University of New England Publishing Unit, Sydney, Austr.

Leslie, D.M., Jr., and E.E. Starkey. 1985. Fecal indices to dietary quality of cervids in old growth forests. J. Wildl. Manage. 49:142-146.

Leslie, D.M., Jr., and E.E. Starkey. 1987. Fecal indices to dietary quality: a reply. J. Wildl. Manage. 51:321-325.

Mason, J.C., and F. White. 1971. The digestion of bacterial mucopeptide constituents in sheep. 1 . The metabolism of 2,6 diaminopimetic acid. J. Agr. Sci. 55:371-376.

McLeod, M.N. 1974. Plant tannins-Their role in forage quality. Nutr. Abs. Rev. 44:803-815.

Milic, B.J., S. Stojanvic, and N. Vucurevic. 1972. Lucerne tannins. II. Isolation of tannins from lucerne, their nature and influence on the digestive enzymes in vitro. J. Sci. Food Agr. 23:1157-1162.

Mould, E.D., and C.T. Robbins. 1981. Nitrogen metabolism in elk. J. Wildl. Manage. 45:323-334.

Montgomery, D.C., and E.A. Peck. 1982. Introduction to linear regression analysis. John Wiley \& Sons, New York.

Mubanga, G., J.L. Holechek, R. Valder, and S.D. Schemnitz. 1985. Relationships beween diet and fecal nutritive quality in male deer. Southwestern Natur. 30:573-578.

Naik, A.H. 1967. Chemical composition of Tanzania feedstuff. E. Afr. Agr. Fr. J. 33:201-205.

Nastis, A.S., and J.C. Malechek. 1981. Digestion and utilization of nutrients in oak browse by goats. J. Anim. Sci. 53:283-291.

Olson, P.D. 1984. Influence of stocking rate on nutritive intake of steers grazing a short-duration grazing system. Ph.D. Diss. Texas A\&M University, College Station.

Orskov, E.R. 1982. Protein nutrition in ruminants. Academic Press, New York, NY.

Price, M.L., and L.G. Butler. 1984. Tannins and nutrition. Purdue Univ. Agr. Exp. Sta. Bull. 272.

Raymond, W.F. 1948. Evaluation of herbage for grazing. Nature (Lond.) 161:937-938.

Robbins, C.T. 1983. Wild life feeding and nutrition. Academic Press, New York, NY.

SAS. 1982. User's guide: basics. SAS Institute Inc., Cary, NC.

Shaabani, S.B., J.W. Stuth, and R.M. Hansen. 1986. Use of fecal nitrogen indices to predict cattle diet qùality, p. 161-174. In: Range Development and Research in Kenya, Winrock Internat. Morrilton, Ark.

Sidahmed, A.E., J.G. Morris, L.J. Koony, and S.R. Radosevich. 1981. Contribution of mixtures of three chaparral shrubs to the protein and energy requirements of Spanish goats. J. Anim. Sci. 53:1391-1400.

Sparks, D.R., and J.C. Malechek. 1968. Estimating percentages of dry weight in diets using a microscope technique. J. Range Manage. 21:264-265.

Stuth, J.W., J.R. Brown, P.D. Olson, M.R. Araujo, and H.D. Aljoe. 1987. Effects of stocking rate on critical plant-animal interactions in a rotational grazed Schizachyrium-Paspalum savanna, p. 115-139. In: F.P. Horn, J. Hodgson, J.J. Mott, R.W. Brougham (ed.) Grazing-Lands Research at the Plant-Animal Interface. Winrock Internat., Morrilton, Ark.

Tamir, M., and E. Alumot. 1969. Inhibition of digestive enzymes by condensed tannins from green and ripe carobs. J. Sci. Food Agr. 20:199-202.

Van Soest, P.J. 1982. The nutritional ecology of the ruminant. O\&B Books Inc., Corvallis, Ore.

White, T. 1957. Tannins-their occurence and significance. J. Sci. Food Agr. 8:377-385.

Wofford, H., J.L. Holechek, M.L. Galyean, J.D. Wallace, and M. Cardenas. 1985. Evaluation of fecal indices to predict cattle diet quality. J. Range Manage. 38:450-454. 